\title{
The Impact of Monetary Policy on Financial Market in South Africa: A VAR Analysis
}

\author{
*Flavien Fokou Noumbissie, Itumeleng Pleasure Mongale \\ North-West University (Mafikeng Campus), South Africa \\ *flavienfokou@outlook.com
}

\begin{abstract}
Like in many other countries, the South African financial market facilitates the process of raising capital by channelling funds to more productive economic activity, thereby building the nation's economy while enhancing job opportunities and wealth creation. The aim of this paper is to assess the impact of monetary policy on financial market in South Africa. It is important to constantly look into this interaction since policy decisions have a direct influence on financial market. A negative response from the market side may jeopardise economic stability. The study uses the vector autoregressive (VAR) model to evaluate the impact of monetary policy on financial market in South Africa. The model consists of five policy instruments as variables; namely: money supply (M3), real exchange rate(ER), discount Rate (R), consumer price index (CPI), gross domestic product (GDP) and the two market related variables: Stock market turnover (S) and Bond market turnover (B). Data is obtained from SARB and OECD databases for a period of 53 quarters from 2000:Q1 to 2013:Q1. By the use of impulse response function (IRF), the study found that given current economic situation in South Africa, stock market turnover reacts positively to money supply; discount rate; real exchange and GDP shocks. On the other hand stock market turnover reacts negatively to CPI economic shocks. To correct CPI negative impact on markets, we suggest that the policymakers could envisage a contractionary monetary policy translated by a proportional cut in money supply through the sales of government securities.
\end{abstract}

Keywords: Monetary policy shocks, financial markets, Vector autoregressive model, impulse response function, South Africa

\section{Introduction}

Like in many other countries, the South African financial market facilitates the process of raising capital by channelling funds to more productive economic activity, thereby building the nation's economy while enhancing job opportunities and wealth creation. The South African financial market is composed of the Johannesburg Stock Exchange (JSE) and the Bond Exchange of South Africa (BESA). It is important to mention the close link between JSE and BESA to the extent that BESA appears to be part of JSE. That being the case, the study focuses on the JSE, which is the $19^{\text {th }}$ largest stock exchange in the world. Its main lines of business are: listings, trading, clearing and settlement services, technology and related services and information product sales (JSE report, 2008). Understanding developments in the financial markets is a cornerstone for monetary policy making (Weber, 2008). The latest empirical authors such as Naraidoo \& Raputsoane, (2013), Joyce et al., (2008) among others find a strong correlation between monetary policy and financial market development. In general, stock and bonds markets also have a counter effect on macroeconomic policy. Through monetary policy transmission mechanism, the impact of monetary policy tools over the policy variables is more or less indirect. The most direct and immediate effects of monetary policy actions such as the changes in the central bank's bill rate, take place in the financial markets. By affecting asset prices and returns, policymakers try to modify economic behaviour in ways that will help to achieve their ultimate objectives (Lkhagvajav et al., 2008).

Loayza \& Schmidt-Hebbel (2002) point out that the main requirement for a good implementation of a monetary policy is an accurate assessment of how fast the effects of policy actions propagate to the other parts of the economy and how important they could be. Furthermore, it implies a perfect understanding of process through which monetary policy affects real economic activities. The transmission mechanism of monetary policy works through various channels, affecting different variables and markets at various speeds and intensities. The identification of these transmission channels is important since they determine the most effective set of policy instruments, the timing of policy changes and hence the main restrictions that central banks face in making their decisions. Still on the same issue, the South African Reserve Bank (SARB) (2000) indicates that the four main transmission channels of monetary policy (interest rate, asset price, exchange rate and credit) are all market channels. The South African monetary authorities are currently implementing inflation targeting as a policy framework. They endeavour to set 
and achieve an explicit inflation target within 3 to $6 \%$. The monetary policy actions are executed through changes in the repurchase (repo) rate which directly influences financial market prices. It is also the main instrument used by the SARB to target inflation. The changes in the repo rate should immediately cause a response from an effective interbank market and will, as a result, ensure effective pricing in the money market as a whole. If changes in financial asset prices and returns induced by actions of monetary policy lead to the changes in economic behaviour, understanding how monetary policy affects the broader economy necessarily entails understanding both how policy actions impact financial markets (Bernanke, 2003).

It is a well-known notion that the financial markets influence economies through public perception. They represent important factors in the monetary policy transmission mechanism to the economy and constitute key factors for economic stability and long-term economic growth. On the other hand policymakers' smooth interest rate changes to guarantee financial markets stability and performance. It is therefore important to constantly look into the interaction between domestic markets and monetary policy. Since policy decisions have a direct influence on financial market, a negative response from the market side may jeopardise the overall objectives of policy decisions which can lead to a threat of economic instability. Unlike the related studies such as Alfaro et al. (2004), Arestis et al. (2001), and Calderón and Liu (2003) which focused more on the relationship between financial stability and economic growth through market interactions. The paper focuses on the interaction between monetary policy and financial market in a context whereby the domestic currency (rand) is continuously volatile with respect to the US Dollar. This is based on the premise that a positive interaction between policy and market instruments is a necessary condition towards economic growth and prosperity. This study is driven by the fact that prior studies on the determinants of stock market focus more in the developed markets and as a result an insignificant attention is given to the developing markets. On the same issue Lkhagvajav et al. (2008) argue that quite a number of literatures in economics are policy and market related. They vary from money, banking and to financial market issues. However, relatively few papers to date have attempted to provide an explanation for the market reactions to monetary policy. Therefore this study attempts to take advantage of this research gap to extend the existing literature in the context of emerging markets like South African. Determining such a relationship is not only imperative for academic standpoint but also for policy viewpoint. The study will therefore help to contribute to a body of knowledge about monetary policy and financial market development and the impact of monetary policy tools over the policy variables.

Beside the above stated importance, the study will attempt to find answers to the following questions:

- What is the reaction of South Africa's stock market turnover to changes in policy instruments?

- What is the impact of monetary policy instruments innovations over bond market turnover in South Africa?

- What is the response of policy instruments to shocks from both stock market return and bond market return in South Africa?

- What is the interaction between stock market return and bond market return in South Africa?

This study is divided in to six parts: Section 1 is an introduction; Section 2 is a review of literature; Section 3 describes the research methods which include data and model specification; Section 4 deals with results and discussion; and Section 5 is the concluding remarks and Section 6 presents the study's recommendations.

\section{Literature Review}

Koivu (2010) investigated the impact of monetary policy on the household consumption via stock housing prices in China using the structural vector auto regression model. The study found that a loosening of China monetary policy leads to higher asset prices, which in turn are linked to the household consumption. There is positive relationship between asset prices and household consumption in China. The study also revealed that the possibilities of influencing house behaviour in China via monetary policy are limited due the fact people have limited access to external finance. In this paper we use the same approach to study the impact of monetary policy in South Africa over stock market bond market.

Adarov \& Tchaidze (2011) studied the development of financial markets in four central European countries (Czech Republic; Hungary; the Slovak Republic and Poland) which seem less developed than the ones in advanced European countries. Government bond markets are more important than private bond, 
private credit, and equity markets that still lag behind. Government bond markets are measured by their size expressed as market capitalisation. They found that the differences observed between public and private markets cannot be explained only by macroeconomic variables, but incorporating indicators of institutional development and external funding eliminates the gap in the case of the equity and private credit markets. However, for the private bond market a significant gap remains even after accounting for these factors. In a related matter Bonga-Bonga (2010) examines how short-term and long-term interest rates react to supply, demand and monetary policy shocks in South Africa. He uses credit extension, real domestic product, repo rate and consumer price index as variables. The study found a positive correlation between the two interest rates after a monetary and demand shock and a negative correlation after a supply shock and concludes that the operation of the monetary transmission mechanism should be effective in South Africa. This study is similar to the one done by Lkhagvajav, et al (2008) where the effects of monetary policy on bond market in Mongolia were analysed using VAR model with six variables (inflation, lending rate, Central Bank Bills rate, exchange rate, money supply and bond market return). We analyse the impact of monetary policy on both stock and bond market in South Africa using VAR model as well with seven variables (money supply; discount rate; real exchange rate; consumer price index; GDP; stock market and bond market turnover).

\section{Methodology}

Data and Model specification: The model of the study consists of seven variables with a time series data collected from the SARB database and the Organization for Economic Co-operation and Development (OECD) for period of 2000:Q1 to 2013:Q1. Based on studies such as Shan(2002), Eita(2012) and Imoudu (2012) a period of 53 quarters data is considered to warrant a sound conclusion in this study. Among these variables, four of them are policy related series: Money Supply $\left(\mathrm{M}_{3}\right)$, Real Exchange Rate(ER), Discount Rate (R) and Consumer Price Index (CPI). Real GDP is the non-policy related variable and it gives a perfect indication of macroeconomic performance. The last two are market related variables namely, Bonds market turnover (B) which is calculated as the total value of bonds traded on BESA and the stock market turnover (S) which is calculated as the total value of shares traded on the JSE. Unlike GDP and CPI data which were provided quarterly, the rest are monthly data. To ease calculations the study uses natural logarithm of all data. Log transformation insures better fit of data by reducing the size of residuals for variables with big values. In the model testing, the stock market turnover will be regarded as the dependent variable. This means that stock market turnover will be expressed as a function of other series:

$S=f(B, M 3, R, E R, C P I, G D P)$

1

and as a linear

$$
S=\sigma_{1} \beta_{t}+\sigma_{2} M 3_{t}+\sigma_{3} R_{t}+\sigma_{4} E R_{t}+\sigma_{5} C P I_{t}+\sigma_{6} G D P_{t}+\varepsilon_{t}
$$

where

$\begin{array}{lll}\mathrm{S} & = & \text { Stock market turnover } \\ \mathrm{B} & = & \text { Bond market turnover } \\ \mathrm{M} 3 & = & \text { Money supply } \\ \mathrm{R} & = & \text { Discount rate } \\ \mathrm{ER} & = & \text { Real exchange rate } \\ \mathrm{CPI} & = & \text { Consumer price index } \\ \mathrm{GDP} & = & \text { Gross domestic product } \\ \sigma & = & \text { Represent parameters of the model which all real numbers } \\ \varepsilon & = & \text { Error term }\end{array}$

Method: This study uses the Vector autoregressive (VAR) analysis to study the impact of monetary policy on financial market in South Africa.VAR is an econometric technique used to estimate multivariate time series and it consists of a set of system of multiple regression equations characterised by the fact that all variables of interest are endogenous and explained by their own lags. Explanatory variables are the same for all the equations and are mainly lagged variables. VAR model is an $\mathrm{n}$-equation and $\mathrm{n}$ variables linear model in which each variable is in sum explained by its own lagged values, plus current and past values of 
the remaining $\mathrm{n}-1$ endogenous variables. The standard practice in VAR analysis is to report results from unit root tests, Johansson cointegration tests and impulse responses function (Stock \& Watson, 2001).The main purpose of employing the IRF is to analyse the dynamic behaviour of the model, so there is a need for a common ordering of variables. Based on Hossain (2008) the variables that are not caused by any another variables in the system will be placed first in the list of ordering and the rest are ordered according to the correlation among these variables. The target variable will be put at the last in the ordering.

\section{Results and Discussion}

Unit root test: It is always relevant to determine the nature of a unit root (stationarity) when dealing with economic variables. Stationary variables are series presenting constant mean, variance and constant auto covariance for every given lag order, therefore using non-stationary series may cause spurious regressions. In other words regressing non-stationary variables under standard measures might produce valueless and biased results despite the appearance of coefficient estimates and the high value of the coefficient of correlation $\left(\mathrm{R}^{2}\right)$. The unit root test helps to detect the existence or non-existence of unit roots in data series, hence enabling the researcher to know whether variables are stationary or not. The following unit roots tests are conducted to test for the presence of unit root in our series: the Augmented Dickey-Fuller (ADF) test and Phillips-Perron (PP) technique for more accuracy. These tests are based on the following assumptions:

$$
\begin{aligned}
& H_{0}: \text { if } \delta=0 \text { Existence of unit root } \\
& H_{1}: \text { if } \delta \neq 0 \text { The existence of unit root is rejected }
\end{aligned}
$$

A maximum of 4 lags is automatically selected by EViews 7 for the ADF test, using Schwartz Information Criterion (SIC) as recommended by Brooks (2008) for quarterly data. As far as PP test is concerned, the default spectral estimation method is Bartlett Kernel with an automatic selection of Newey-West Bandwidth. The interpretation of the result of the two unit root tests is based on comparing their $t$ statistics with their critical values:

$$
\begin{aligned}
& \text { If } t^{*}>\mathrm{ADF} \text { / PP critical values: Acceptance of null hypothesis (unit root exists). } \\
& \text { If } t^{*}<\mathrm{ADF} / \mathrm{PP} \text { critical values: Rejection of null hypothesis (unit root does not exist). }
\end{aligned}
$$

Finally the stationary variables will be incorporated at levels whereas the transformation of other

\begin{tabular}{|c|c|c|c|c|c|}
\hline Variable & Level of test & $\begin{array}{l}\text { Number of } \\
\text { lags }\end{array}$ & $\begin{array}{l}\text { t-statistics } \\
\text { (ADF test) }\end{array}$ & $\begin{array}{l}\text { Critical value } \\
5 \%\end{array}$ & Conclusion \\
\hline \multirow[t]{2}{*}{ M3 } & Level & 3 & -1.133851 & -3.504330 & Unit root \\
\hline & $1^{\text {st }}$ Difference & 0 & -5.251992 & -3.500495 & No unit root \\
\hline \multirow[t]{2}{*}{ ER } & Level & 0 & -2.077593 & -3.498692 & Unit root \\
\hline & $1^{\text {st }}$ Difference & 0 & -6.598246 & -3.500495 & No unit root \\
\hline \multirow[t]{2}{*}{$\mathrm{R}$} & Level & 1 & -2.810674 & -3.500495 & Unit root \\
\hline & $1^{\text {st }}$ Difference & 0 & -3.651304 & -3.500495 & No unit root \\
\hline \multirow[t]{2}{*}{ GDP } & Level & 0 & -1.326018 & -3.498692 & Unit root \\
\hline & $1^{\text {st }}$ Difference & 0 & -7.157429 & -3.500495 & No Unit root \\
\hline \multirow[t]{3}{*}{ CPI } & Level & 1 & -2.286216 & -3.500495 & Unit root \\
\hline & $1^{\text {st }}$ Difference & 0 & -3.419675 & -3.500495 & Unit root \\
\hline & $2^{\text {nd }}$ Difference & 0 & -7.531772 & -3.502373 & No unit root \\
\hline \multirow[t]{2}{*}{ B } & Level & 0 & -2.763791 & -3.498692 & Unit root \\
\hline & $1^{\text {st }}$ Difference & 2 & -5.142863 & -3.504330 & No unit root \\
\hline \multirow[t]{2}{*}{ S } & Level & 0 & -1.952895 & -3.498692 & Unit root \\
\hline & $1^{\text {st }}$ Difference & 0 & -8.363450 & -3.500495 & No unit root \\
\hline
\end{tabular}
variables from non-stationary to stationary will be completed be using the difference-stationary process. The summary of our ADF and PP tests results are shown in the Tables 1 and 2 respectively.

Table 1: Unit root test results (ADF)

Both ADF and PP tests results reveal the presence of unit root in all series at the first level at 5\% confidence interval. In other words all the series are non-stationary at the levels. Therefore stationarity is 
achieved in all the series after first differentiation except for CPI ${ }^{1}$. The unit root of the CPI series is only cleared after a second differentiation whereby the critical values led to the same conclusion of stationary series. Engsted et al. (1997) refer to this type of circumstance as multicointegration ${ }^{2}$. According to Enders (2010) it is possible to find equilibrium relationships among groups of variables that integrated of different orders. Hence we generated new data series which from now on will constitute our new variables which are basically all the differenced values of the previous ones and they provide the advantage of been stationary. The next step is to perform the Johansen cointegration test because both the ADF and PP tests results have confirmed that the series in the model are cointegrated therefore the errors are stationary.

Table 2: Unit root test results (PP)

\begin{tabular}{|c|c|c|c|c|c|}
\hline Variable & Level of test & Bandwidth & $\begin{array}{l}\text { t-statistics } \\
\text { (PP test) }\end{array}$ & $\begin{array}{l}\text { Critical value } \\
5 \%\end{array}$ & Conclusion \\
\hline \multirow[t]{2}{*}{ M3 } & Level & 4 & -0.072084 & -3.498692 & Unit root \\
\hline & $1^{\text {st }}$ Difference & 4 & -5.334193 & -3.500495 & No unit root \\
\hline \multirow[t]{2}{*}{ ER } & Level & 3 & -2.318704 & -3.498692 & Unit root \\
\hline & $1^{\text {st }}$ Difference & 2 & -6.581687 & -3.500495 & No unit root \\
\hline \multirow[t]{2}{*}{$\mathrm{R}$} & Level & 3 & -1.963516 & -3.498692 & Unit root \\
\hline & $1^{\text {st }}$ Difference & 3 & -3.669380 & -3.500495 & No unit root \\
\hline \multirow[t]{2}{*}{ GDP } & Level & 2 & -1.364020 & -3.498692 & Unit root \\
\hline & $1^{\text {st }}$ Difference & 6 & -7.296324 & -3.500495 & No unit root \\
\hline \multirow[t]{3}{*}{ CPI } & Level & 4 & -1.770300 & -3.498692 & Unit root \\
\hline & $1^{\text {st }}$ Difference & 0 & -3.419675 & -3.500495 & Unit root \\
\hline & $2^{\text {nd }}$ Difference & 5 & -7.921087 & -3.502373 & No unit root \\
\hline \multirow[t]{2}{*}{ B } & Level & 4 & -2.859727 & -3.498692 & Unit root \\
\hline & $1^{\text {st }}$ Difference & 8 & -8.222412 & -3.500495 & No unit root \\
\hline \multirow[t]{2}{*}{$S$} & Level & 1 & -1.900483 & -3.498692 & Unit root \\
\hline & $1^{\text {st }}$ Difference & 4 & -8.649158 & -3.500495 & No unit root \\
\hline
\end{tabular}

Cointegration test: Johansen cointegration test: After the determination of the optimal lag order we test if the series are cointegrated. This study follows the Johansen approach because unlike the EngleGranger, the Johansen setup consents the testing of hypotheses about the equilibrium relationships between the variables. This allows a researcher to test a hypothesis about one or more coefficients in the cointegrating relationship (Brooks, 2008). Our VAR model will consider constants and deterministic trend illustrated in equation 3 :

$$
\Delta Y_{t}=\alpha+\beta T+\Pi Y_{t-1}+\gamma_{i} \sum \Delta Y_{t-i}-e_{t}
$$

According to Johansen (2005), the vector of endogenous variables $Y_{t}$ is integrated of order 1 , noted as I(1), if after differentiation with its own lag the obtained relation is a linear process with the inverse of the coefficient vector $\Pi^{-1}$. If there is a vector $\theta \neq 0$ so that $\theta^{\prime} Y_{t}$ is stationary, then $Y_{t}$ is said to be cointegrated with cointegrating vector $\theta$. In other words if two vectors $X_{t}$ and $Y_{t}$ are both integrated of the same order and they can be written as linear combination called vector $Z_{t}=Y_{t}-\beta X_{t}$ with $Z_{t}$ integrated of order 0 , then vectors $X_{t}$ and $Y_{t}$ are also said to be cointegrated. This implies a long-run equilibrium relation between the two vectors and their relationship is stationary and converges. Any other divergence will be temporary. The Johansen cointegration test serves to determine the equations of long run equilibrium among the series. Hence we assess the sensitivity of test results to specification type. By opting for an overall result of all set of assumptions in connection with cointegration test specifications, the Lag intervals selected is 1 to 4 at 5\% significance level. The tests results are illustrated in Table 3.

\footnotetext{
1It is important to remember that at this stage all series are in natural logarithms e.g: CPI=LOG (CPI) and so forth.

${ }^{2}$ Cointegration between the cumulated cointegration errors at one level of cointegration with the original variables, the implied consequences with respect to estimation and testing are non-trivial.
} 
Table 3: Johansen cointegration test allowing linear deterministic trend Intercept (no trend) in CE and test VAR

\begin{tabular}{llllll}
\hline $\begin{array}{l}\text { Hypothesised } \\
\text { No of CE(s) }\end{array}$ & Eigenvalue & $\begin{array}{l}\text { Trace } \\
\text { Statistic }\end{array}$ & $\begin{array}{l}\mathbf{0 . 0 5} \\
\text { Critical } \\
\text { value }\end{array}$ & $\begin{array}{l}\text { Max-Eigen } \\
\text { Statistic }\end{array}$ & $\begin{array}{l}\mathbf{0 . 0 5} \\
\text { Critical Value }\end{array}$ \\
\hline None & 0.827184 & $222.3200^{*}$ & 125.6154 & $84.26537^{*}$ & 46.23142 \\
At most 1 & 0.650375 & $138.0546^{*}$ & 95.75366 & $50.44288^{*}$ & 40.07757 \\
At most 2 & 0.517967 & $87.61172^{*}$ & 69.81889 & $35.02762^{*}$ & 33.87687 \\
At most 3 & 0.377538 & $52.58410^{*}$ & 47.85613 & 22.75552 & 27.58434 \\
At most 4 & 0.337134 & $29.82858^{*}$ & 29.79707 & 19.73675 & 21.13162 \\
At most 5 & 0.158056 & 10.09183 & 15.49471 & 8.258017 & 14.26460 \\
At most 6 & 0.037484 & 1.833815 & 3.841466 & 1.833815 & 3.841466 \\
\hline
\end{tabular}

Trace test indicates 5 cointegrating eqn(s) at the 0.05 level

Max-eigenvalue test indicates 3 cointegrating eqn(s) at the 0.05 level

*denotes rejection of the hypothesis at the 0.05 level

The trace test statistic depicts five (5) cointegrating equations at 5\% level, implying the rejection of the null hypothesis of no cointegration of the series. On the other hand, the maximum eigenvalue statistic indicates the presence of three (3) cointegrating equations at 5\% level. Banerjee et al. (1993) advocate that if there are different results between the trace statistic and the maximum eigenvalue test, the maximum Eigenvalue is preferred. Hence we follow the maximum eigenvalue test results and accept three (3) as the appropriate number of cointegrating equations for our model. The presence of cointegrating vectors suggests the existence of the linear combination among the seven series, signifying the presence of a long run relationship among them. EViews package provides estimates of the cointegrating relation $\alpha$ based on the normalisation $\beta^{\prime} S_{11} \beta=1$ and also estimates of the adjustment parameter $\alpha$ (Table 4). We may now express the relationship of series while considering stock market turnover (DS) ${ }^{3}$ as the explained series.

Table 4: Normalised cointegrating equation

\begin{tabular}{|c|c|c|c|c|c|c|}
\hline \multicolumn{7}{|c|}{ Normalised cointegrating coefficients (standard error in parentheses) } \\
\hline DS & DB & DM3 & DR & DER & DCPI & DGDP \\
\hline \multirow[t]{2}{*}{1.000000} & -1.277045 & -12.09107 & 0.925579 & -5.824801 & -41.08200 & 46.51607 \\
\hline & $(0.40490)$ & $(2.21087)$ & $(0.72353)$ & $(1.13249)$ & $(10.7639)$ & $(6.00839)$ \\
\hline
\end{tabular}

Stock market performance (DS) normalised to unity as endogenous variable of the regression. With the estimated cointegrated vector, the associated coefficients represent the long run elasticity of a given series to stock market turnover. The cointegrated vector is expressed as follows:

$$
\begin{gathered}
D S=-3.277045 D B-12.09107 D M 3+0.925579 D R-5.824801 D E R \\
-41.08200 D C P I+46.51607 D G D P=0 \\
D S=3.277045 D B+12.09107 D M 3-0.925579 D R+5.824801 D E R \\
+41.08200 D C P I-46.51607 D G D P=0
\end{gathered}
$$

Equation 5 illustrates a positive relationship between stock market performances (DS); money supply (DM3); CPI (DCPI); real exchange rate (DER) and Bond market turnover (DB). It implies that a $1 \%$ increase in money supply causes stock market turnover to rise by $12.091 \%$. In the same logic, the appreciations of bond market turnover by $1 \%$ induces stock market turnover to increase by $3.277 \%$ and a percentage increase in CPI boosts stock market turnover by $41.082 \%$. Finally a rise of real exchange rate by $1 \%$ generates an increase of $5.825 \%$ in stock market turnover. In line with economic theory, the positive relationship between stock market performance and CPI could translate into a long run effect of the inflationary conditions over stock market in South Africa. About the real exchange rate, the positive relationship could be linked to the increase of foreign investments when domestic currency depreciates. On the other hand the expansionary monetary policy which is explained by the increase of money supply

${ }^{3} \mathrm{DS}$ is the generated stationary series after unit root test. As all other generated stationary series DS stands for its original variable. Meaning DS represents stock market turnover (S) and so forth. 
aims at stimulating aggregate spending. Hence a rise in money supply should rationally induce an increase in the stock market turnover. From equation 5 we can also notice a negative relationship amongst stock market turnover; discount rate and GDP. An increase in GDP and discount rate by $1 \%$ leads stock performance to decrease by $46.516 \%$ and $0.926 \%$. The existence of cointegrating vectors in the long run implies the presence of corresponding vector error correction model for short run dynamics between series.

Vector Error Correction Model (VECM): VECM serves to estimate both short term and long run effects of explanatory time series. It corrects long run disequilibrium through short run adjustments, leading the system to short run equilibrium. We establish VECM considering the 3 cointegrating vector derived from the Johansen cointegration test, with lags interval of 1 to 2 .

Table 5: Summary of the VECM Estimates

\begin{tabular}{|c|c|c|c|}
\hline Variables & Coefficients & Standard Error & t - statistic \\
\hline $\mathrm{D}(\mathrm{DS})$ & -0.288026 & 0.24565 & -1.17251 \\
\hline $\mathrm{D}(\mathrm{DB})$ & -0.087283 & 0.23763 & -0.36731 \\
\hline D(DM3) & -0.156484 & 1.45582 & -0.10749 \\
\hline $\mathrm{D}(\mathrm{DR})$ & 1.285450 & 0.49342 & 2.60516 \\
\hline $\mathrm{D}(\mathrm{DER})$ & 2.303800 & 0.58008 & 3.97152 \\
\hline $\mathrm{D}(\mathrm{DCPI})$ & 13.34640 & 3.52477 & 3.78646 \\
\hline $\mathrm{D}(\mathrm{DGDP})$ & -3.490266 & 2.77399 & -1.25821 \\
\hline$E C$ & -0.748544 & 0.24014 & -3.11713 \\
\hline Constant & -0.001712 & 0.01734 & -0.09876 \\
\hline \multicolumn{4}{|c|}{ R-squared $=0.77$} \\
\hline
\end{tabular}

Since VECM is a system of equations, the error term of the CointEq2 is negative $(-0.748544)$ and significant. The implication is that the estimated coefficient of -0.75 indicates that about $75 \%$ of this disequilibrium is corrected between 1 quarter. The coefficient of correlation (R-squared of around 77\%) of the series reveals that the VECM significantly translate short-term adjustments in all seven variables and it explains adjustments in all series according to short run changes. Based on the complete VECM results, the error correction terms indicate that stock market turnover (DS); bond market turnovers (DB), discount rate (DR) and real exchange rate substantially adjust to long run shocks affecting natural equilibrium. Although GDP presents two significant alpha coefficients, it does not adjust to its respective cointegrating equation ${ }^{4}$.

\section{Figure 1: Inverse roots of AR characteristic polynomial}

Inverse Roots of AR Characteristic Polynomial

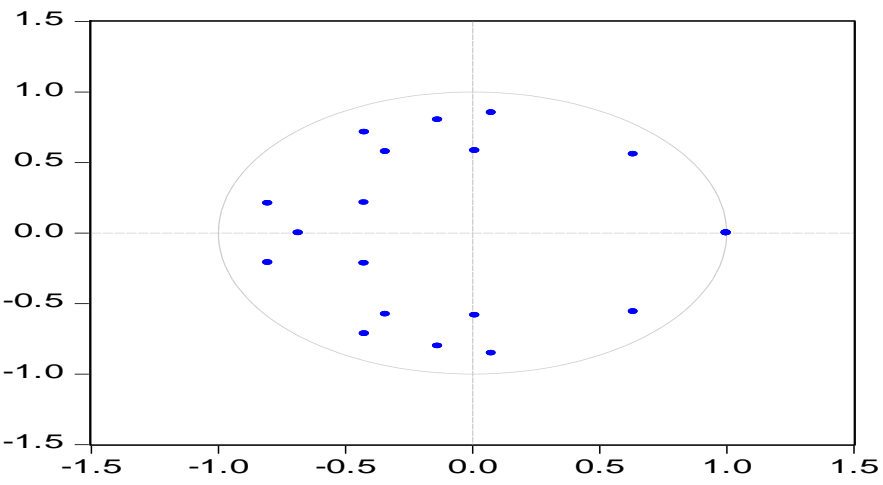

VEC stability condition check: According to Agung(2011) to conduct further analyses of the VECM, the VEC stability condition check of the model is done. It is a type of a diagnostic test used to determine whether the model meets the stability properties of a good model. The results in Figure 1 show that most of the roots of the characteristic AR polynomial have absolute value less than one and fall inside the unit circle. However the modulus of one root is equivalent to one, this is statistically acceptable since the root does not lie outside the unit circle. The implication is that our VAR model satisfies the stability condition

${ }^{4}$ Due to the absence of desired negative sign on coefficient 
and it is statistically acceptable. To validate the robustness of the results and to investigate whether the long run relationships established are stable over the period of study several diagnostic test procedures were considered and the results are summarised in Table 6 .

Table 6: Summary of diagnostic tests

\begin{tabular}{llll}
\hline Test for: & Test & p-value & Conclusion \\
\hline Normality & JB & 0.94 & Accept $\mathrm{H}_{\mathrm{o}}$ \\
Serial correlation & LM & 0.28 & Accept $\mathrm{H}_{\mathrm{o}}$ \\
Heteroskedasticity & White (without cross terms) & 0.54 & Accept $\mathrm{H}_{\mathrm{o}}$ \\
\hline
\end{tabular}

Based on Table 6 the estimated model passed diagnostic tests of normal distribution, no serial correlation and no heteroskedasticity at $5 \%$ significant level. Knowing that the model is fit we proceed with Impulse response function.

Impulse response function analysis (IRF): The IRF analysis helps this study to investigate the impacts of specific variable innovations on other series over a period of 52 quarters. A null value indicates that a particular innovation has no effect on a given variable which continues on the same path that it would have followed if there was no shock. A positive or negative value indicates that the shock causes the given variable to be above or below its natural path. The analyses of the interaction between stock market turnover and bond market turnovers in South Africa in Figure 2 reveal that the stock market turnover appears to be an increasing function of money supply; discount rate; real exchange and GDP. On the other hand one standard deviation of CPI induces a decrease of stock market turnover. Average changes in money supply cause the bond market turnover to fall whereas average changes from DR; DER; DCPI and DGDP series generate increase in the bond market turnover. Accumulated response of policy instruments towards stock market innovations reveals that in South Africa, stock market innovations cause positive change in money supply, discount rate and GDP. On average the unexpected changes from stock market turnover negatively affect real exchange rate and CPI.

\section{Conclusion}

The aim of this study is to analyse the impact of monetary policy over financial market in South Africa. The need for this research lies on the fact that most direct and immediate effects of monetary policy actions towards achievement of its goals are in the financial markets. The main requirement for a good implementation of monetary policy is an accurate assessment of how fast the effects of policy actions propagate to other parts of the economy. The study went further to analyse the reaction of South African stock and bond market turnover to changes from policy instruments and to examine the response of policy instruments to shocks from both stock market return and bond market return in South Africa.

The ADF and the PP unit root tests show that all series are stationary at level and unit root problem is cleared from series after first differencing. Hence we generated new stationary series that were named respectively: DS; DB; DM3; DR; DER; DCPI and DGDP. The Johansen cointegration test indicates the presence of three (3) cointegrating equations among the series. The implication is that there is an existence of linear combination among the seven (7) series, signifying the presence of long run equilibrium. The computations of VECM showed that beta parameters of all three long run equilibrium equations were significant. Error correction terms indicated that stock market turnover (DS); bond market turnovers (DB), discount rate (DR) and real exchange rate could substantially adjust to long run innovations affecting natural equilibrium. Although DGDP presented two significant alpha coefficients it showed no sign of possible adjustment to its respective long run cointegrating equations. The estimated model satisfies the stability condition, it is statistically acceptable and it has also passed the diagnostic tests of normal distribution, no serial correlation and no heteroskedasticity.

The effects of monetary policy instruments over stock and bond market performances were explained through IRF. The study found out that accumulated responses of DS towards monetary instruments indicates that stock market turnover in South Africa is an increasing function of money supply, discount rate, real exchange and GDP at different proportions. On the other hand, stock market turnover seemed to be a decreasing function of DCPI as expected by economic theory. When prices rise economic agents tend to save and invest less. The bond market turnover appeared to be a decreasing function of DM3 and an increasing function of DR; DER; DCPI and DGDP. Regarding counter effects of South African markets over 
policy instruments, it appears that the accumulated responses of policy instruments to stock market innovations show that stock market innovations caused positive changes in money supply, discount rate and GDP. On average, the unexpected changes from stock market turnover negatively affect the real exchange rate and CPI. Accrued responses of monetary policy aggregates towards DB innovations revealed that bond market turnover in South Africa has a positive outcomes on DM3; DR; DCPI ; DGDP and negative upshot on DER. Finally about the interaction between DS and DB, the IRF indicates that stock market gross revenue positively impacted bond market sales. In contrast to that, bond market performance negatively influences the stock market sales.

Figure 2: IRF of interaction between stock and bond markets.

Response to Cholesky One S.D. Innovations
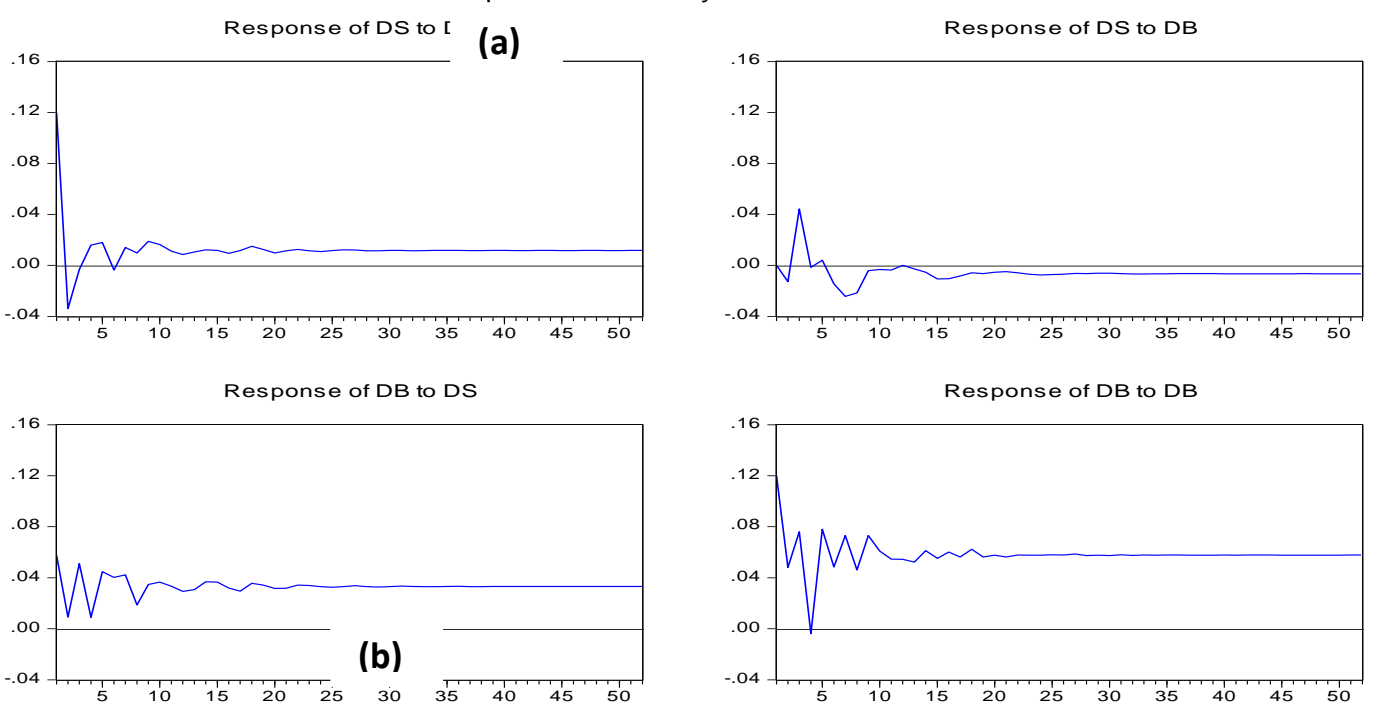

Accumulated Response to Cholesky One S.D. Innovations

Accumulated Response of DS to DS

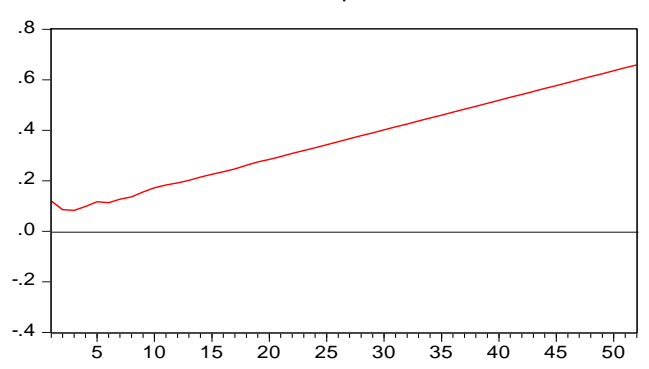

Accumulated Response of DB to DS

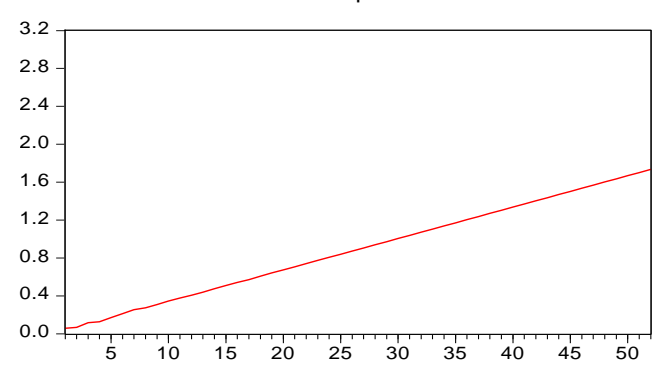

Accumulated Response of DS to DB

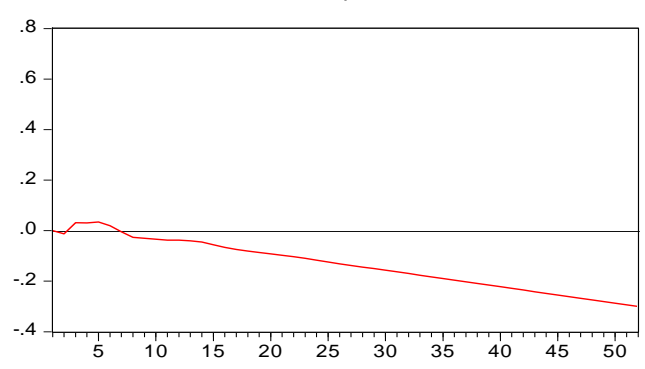

Accumulated Response of DB to DB

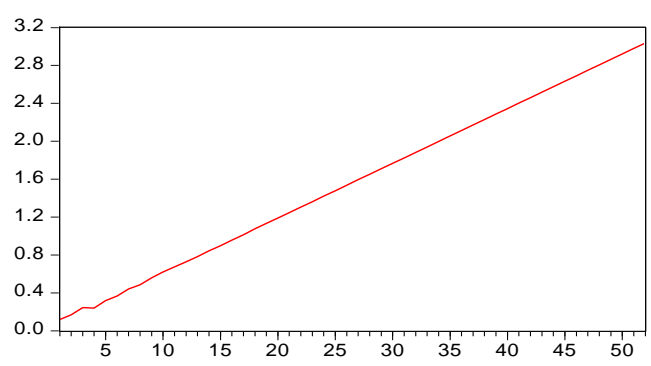

On the other hand direct response of DS towards DB innovations illustrates a decrease in stock market turnover. We can note that direct response of DS to DB shocks mostly happens below the null value. In general, the accumulated response of stock market turnover to innovations from bond market turnover shows that innovations from stock market turnover generate increase in bond market turnover, whereas economic shocks from bond turnover induce decline of stock market turnover.

Recommendations: It has been observed that accrued effect of DCPI negatively impact stock market turnover in South Africa. Although DCPI appeared to positively affect bond market turnover, it is 
important to note that it might just be a nominal effect. In the sense that DCPI rise could just inflate bond market turnover nominal return without improving bond market real yield. To remedy the situation, the monetary authorities may adjust discount rate or money supply through a relative contractionary policy programme. In other words a contractionary monetary policy could be envisaged by monetary authorities. It could happen as a proportional cut in money supply through the sales of market securities by SARB. Alternatively it may still take place through proportional reduction of the discount rate. A plethora of topics or studies could be drawn out of this research paper. For instance the study could be extended to a broader horizon involving the assessment of monetary policy impact over financial market development in South Africa. In this case, attention will be paid not only on policy impact over market return but spread towards policy impact over market development and sustainability. In the decision making process how do monetary policymakers in South Africa insure greater sustainability and improvement of the South African financial market? This new market analysis could take place in three stages: policy impact over market capitalisation; policy impact over market liquidity and lastly policy impact over market volatility.

\section{References}

Adarov, A. \& Tchaidze, R. (2011). Development of Financial Markets in Central Europe: the Case of the CE4 Countries IMF Working Paper. European Department.

Agung IGN. (2011). Time series data analysis using EViews, New York: John Wiley \& Sons.

Alfaro, L., Chanda, A., Kalemli-Ozcan, S. \& Sayek, S. (2004). FDI and economic growth: The role of local financial markets. Journal of International Economics, 64(1), 89-112.

Arestis, P., Demetriades, P. O. \& Luintel, K. B. (2001). Financial Development and Economic Growth: The Role of Stock Markets. Journal of Money, Credit \& Banking (Ohio State University Press), 33, 16-41.

Banerjee, A., Dolado, J., Galbraith, J. W. \&Henry, D. F. (1993). Co-integration, error correction and the econometric analysis of non stationary data: Advanced texts in econometrics, Oxford: Oxford University Press.

Bernanke, B. S. (2003). RE: Monetary Policy and the Stock Market: Some Empirical Results. Type to AT The Fall 2003 Banking And Finance Lecture Widener University, C., Pennsylvania.

Bonga-Bonga, L. (2010). Monetary Policy And Long-Term Interest Rates In South Africa. International Business \& Economics Research Journal, 9(10), 43-54.

Brooks, C. (2008). Introductory Econometrics for Finance, Cambridge: Cambridge University Press.

Calderón, C. \& Liu, L. (2003). The direction of causality between financial development and economic growth. Journal of Development Economics, 72(1), 321-334.

Eita, J. H. (2012). Modelling Macroeconomic Determinants of Stock Market Prices: Evidence From Namibia. The Journal of Applied Business Research, 28(5)871-884.

Enders, W. (2010). Applied Econometric Time Series (3rd ed),Hoboken: John Wiley and Sons, Inc.

Engsted, T., Gonzalo, J. \& Haldrup, N. (1997). Testing for Multicointegration. Economics Letters, 56, 259266.

Hossain, S. (2008). Econometrics modelling: Frequently asked questions. Cyberjava:

Imoudu, E. C. (2012). The Impact of Foreign Direct Investment on Nigeria's Economic Growth; 19802009: Evidence from the Johansen's Cointegration Approach. International Journal of Business and Social Science, 3(6) 123-134.

Johansen, S. (2005). Interpretation of Cointegrating Coefficients in the Cointegrated Vector Autoregressive Model. Oxford Bulletin of Economics and Statistics, 67(1), 93-104.

Joyce, M., Relleen, J. \& Sorensen, S. (2008). Measuring Monetary Policy expectations from Financial Market instrument. Working series. ECB workshop on the analysis of money.

JSE Report. (2008). Johanesburg Secutity Exchange Limited Annual Report. JSE Annual Report, Johannesburg: JSE Limited.

Koivu, T. (2010). Monetary Policy, Asset Prices and Consumption in China, European Central Bank, Working Paper Series.

Lkhagvajav, B., Batnyam, D. \& Gan-Ochir, D. (2008). Monetary Policy and Bond Market Development: A Case of Mongolia. In: DIVISION, M. P. (ed.). Ulaanbaatar: Bank of Mongolia.

Loayza, N. \& Schmidt-Hebbel, K. (2002). Monetary Policy Functions and Transmission Mechanisms: An Overview. In: LOAYZA, N. \& SCHMIDT-HEBBEL, K. (eds.) Monetary policy: Rules and transmission mechanisms. Series on Central Banking, Analysis, and Economic Policies, Vol. 4. Santiago: Central Bank of Chile.

Naraidoo, R. \& Raputsoane, L. (2013). Financial markets and the response of monetary policy to uncertainty in South Africa. Working PapersUniversity of Pretoria, Department of Economics. 
SARB. (2000). Proposals to improve the functioning of the South African reserve bank's refinancing system and the interbank market, Pretoria: South African Reserve Bank.

Shan, J. (2002). A VAR approach to the economics of FDI in China. Applied Economics, 34, 885-893.

Stock, J. H. \& Watson, M. W. (2001). Vector Autoregressions. The Journal of Economic Perspectives, 15(4), 101-115.

Weber, A. A. (2008). Financial Markets and Monetary Policy. CEPR/ESI 12th Annual Conference: The Evolving Financial System and the Transmission Mechanism of Monetary Policy Basel: Deutsche Bundesbank. 